\title{
Simpson, James.
}

Permanent Revolution: The Reformation and the Illiberal Roots of Liberalism. Cambridge, MA: The Belknap Press of Harvard University Press, 2019. Pp. xiii, 444. ISBN 978-0-674-98713-5 (hardcover) US\$35.

James Simpson, well known for his brilliant contribution to the scholarship of the late Middles Ages, has contributed a distinct and suggestive study of the English Reformation, showing once more how deep scholarship and reading can yield something unexpected and significant not just to scholars but to members of the wider community. So what is surprising? The English Reformation began with "illiberalism," intolerance, literalism, predestination, and the like, and gave the underpinnings, even if transmogrified, of liberalism, freedom of conscience, free will, religious freedom, political constitutional frameworks, and more. Simpson finds the illiberal roots of liberalism in this permanent revolution and so makes more intricate our understanding of the Reformation and what followed to our day. Protestants transformed their own tradition to go from the illiberal to the liberal.

But ever the nuanced scholar and stylist, Simpson shows that the Reformation had illiberal and liberal aspects. One of the best elements of this book is the way it crafts an argument, lucidly but never simplistically, to give a fuller picture than we had before of the oxymoronic aspect of the subtitle. So I began this review with the apparently paradoxical shift from the illiberal to the liberal but will follow Simpson into a much more complex and fascinating account of the waning of the Middle Ages to the Glorious Revolution.

Simpson came to this book in a Milton seminar in which the question of freedom with a precondition arose (ix). This comment on Milton, who for Simpson is a mixture of liberal and illiberal, prompts this study, whose answers are "that Protestantism is a powerfully and necessarily self-conflicted tradition, precisely because its anti-formalism repudiates tradition" (xi). Simpson continues: "In flight from nothing so energetically as from prior forms of itself, Protestantism is best described as an anti-tradition tradition of permanent revolution, forever targeting earlier and/or competing versions of itself (rather than Catholicism) precisely as the source of most lethal threat" (xi). Simpson sees a kinesis within Protestantism, which explains how 1688 was so different from 1517, and argues that evangelism forged the liberalism of 1688 and of today, and he maintains that this early modern evangelism also made illiberal, 
revolutionary evangelical religion in Anglo-American modernity (xi). He also notes his debt to Barbara Lewalksi, a force in Renaissance and Milton studies at Harvard and beyond, and others there and at Melbourne (xi-xii).

According to Simpson, the Whig tradition sees the Reformation as a positive: a source of liberty-personal, religious, and political (1). Simpson follows Herbert Butterfield in arguing that liberty was an accidental result of the Reformation in the pain of what followed, and sees little that is productive in either Protestant or Catholic triumphalism in historiography. This rift between the Catholic Middle Ages and the Protestant Reformation "remains the deepest cultural divide in English literary historiography" (3; see also 2). Arguing for grand narratives in history, Simpson warns against missing the darkness of the Reformation by seeing 1517 through 1688 and, like Zhou Enlai, takes a long view of revolutions (150 years) $(4,8)$. The early Reformation involved a revolutionary evangelical religious culture and was composed of permanent revolution and self-repudiation; revolution was both unsustainable and selfstabilizing. Simpson argues that, except possibly for the history of science, in almost all principal respects the Enlightenment in Britain is "the reflex of religious culture" (11). He signals his central argument: "that the liberal tradition derives from Protestantism by repudiating it" (11). In each chapter, Simpson, who says he is more cultural historian than literary critic, looks at a key elements and performs his "recovery" or "cultural etymology" in which he starts with the present but enacts a recovery from the past to understand better the now (12).

Themes structure the book in seven parts that group the eighteen chapters: Religion as Revolution (chapters 1-2); Working Modernity's Despair (chapters 3-5); Sincerity and Hypocrisy (chapters 6-8); Breaking Idols (chapters 9-11); Theater, Magic, Sacrament (chapters 12-14); Managing Scripture (chapters 15-17); Liberty and Liberties (chapter 18). Although as Simpson notes, each sequence is self-contained, each but the final one involves "a tripartite story," which, with variation, is an "appropriation of powers and carnivalesque, revolutionary energy (c. 1520-1547); revolutionary grief (c. 1547-1625); escaping revolutionary disciplines? (c. 1603-1688)" (3; see 12). Apparently, the last two parts overlap in the years circa 1603 to 1625.

Revolutionary religion, is, for Simpson, a Reformation that is illiberal and proto-liberal (17). In the 1540s, John Bale had predicted a quick transition from intricate to simple, old to new, but a century later Edmund Calamy and John 
Milton observed the opposite (53). Simpson sees despair, or wanhope, as the most dynamic and widespread form of modernity in early modern Europe, and argues that despair in the face of predestination was rare in late medieval literature but usual in the religious experience and writing of the sixteenth and seventeenth centuries, a kind of "modernizing despair" (57). Simpson discusses many poets, including John Donne and George Herbert. As lyric religious poets they work against the extreme psychic challenges of those like William Perkins: i.e., the Calvinist predicament of a despair that produces despair (90-93). Religious and political civil wars had plagued France and the Netherlands and would do so England (97-101). Milton reinvents epic to repress despair (107). Sincerity and hypocrisy had-as Edmund Hall reported in 1548 of Henry VIII at Christmas 1545-been a theme of religious dissension throughout England and among the clergy. Long did this situation persist and could rebound on the speaker or writer $(111,125)$. Protestants could be as hypocritical as the Catholics they accused of hypocrisy (126).

The Toleration Act of 1688-89 and the work of John Locke moved beyond this turbulent intolerance (153-56). Iconoclasm is revolutionary but also based in the Decalogue in the Bible the Protestants sought as their authority (159-61). English iconoclasm began as ebullient but became pitiless (171-72). Milton's Samson Agonistes represents a lone act against idolatry that may be an allegory not just for Samson but for Milton (192-94). The question of magic is also a key to the Catholic Middles Ages, as can be seen in the York Cycle's representation of the miracle of Lazarus and in the Protestant anti-sacral and anti-magical theatre of John Bale, Christopher Marlowe's Faustus, and tracts like that of William Prynne (201-56). Freedom to interpret the scriptures, evangelical hermeneutics, and Milton's literary discourse (his liberty taking liberties) is also part of Simpson's analysis $(220,281,314,342-43)$. Freedom becomes the nub (350). Catholics and Protestants had dark intolerances. How after 1688 can we live in tolerance and freedom? Simpson's book has an urgency.

JONATHAN LOCKE HART

Centre for Reformation and Renaissance Studies

University of Toronto 